\title{
Article \\ The Influence of Mechanical Composition and Mineral Composition of Calcareous Soil on Slope Farmland on Phosphorus Fixation
}

\author{
Weiyi Han, Ye Li * and Hang Yin
}

check for

updates

Citation: Han, W.; Li, Y.; Yin, H. The Influence of Mechanical Composition and Mineral Composition of

Calcareous Soil on Slope Farmland on Phosphorus Fixation. Appl. Sci. 2021, 11, 3731. https://doi.org/10.3390/ app11093731

Received: 29 March 2021

Accepted: 18 April 2021

Published: 21 April 2021

Publisher's Note: MDPI stays neutral with regard to jurisdictional claims in published maps and institutional affiliations.

Copyright: (c) 2021 by the authors. Licensee MDPI, Basel, Switzerland. This article is an open access article distributed under the terms and conditions of the Creative Commons Attribution (CC BY) license (https:// creativecommons.org/licenses/by/ $4.0 /)$.
School of Resource and Environmental Engineering, Wuhan University of Technology, Wuhan 430070, China; echocolate@whut.edu.cn (W.H.); comeon9527@whut.edu.cn (H.Y.)

* Correspondence: whly1218@whut.edu.cn

Abstract: Soil erosion on slope farmland causes the degradation of soil quality and eutrophication of water bodies due to the loss of phosphorus. In order to explore the influence of soil mechanical composition and mineral composition on phosphorus fixation, we selected calcareous soil on slope farmland in the Three Gorges Reservoir area as the research object and separated the samples on the basis of particle size. Next, we determined the content of different forms of phosphorus for each particle size, and then characterized and analyzed the mineral composition. The adsorption performance of each particle size was also studied. The results show that the calcareous soil on slope farmland has a high proportion of coarse fractions, and the carbonate minerals enriched in coarse fractions will fix a large amount of phosphorus and degrade soil quality. As slope farmland is prone to soil erosion, when the soil undergoes selective migration, the loss of fine fractions will increase the proportion of coarse fractions and aggravate soil quality degradation. Meanwhile, because of the large amount of phosphorus adsorbed by fine fractions, the available phosphorus is easily lost with fine fractions, leading to eutrophication of water bodies.

Keywords: phosphorus; particle size; mineral composition; calcareous soil

\section{Introduction}

Slope farmland refers to the cultivated dry land distributed on a hillside. When the landform slope type is between 6 and $25^{\circ}$ and it is cultivated, it can be called slope farmland. At present, the area of arable land in China is about 135 million ha, of which the area of slope farmland is about 30.9 million ha [1], accounting for over one-fifth. Due to the instability of slopes and uneven rainfall [2], slope farmland is prone to soil erosion, which carries soil, nitrogen, phosphorus, and other nutrients into water bodies, leading to siltation of rivers and lakes and eutrophication of water bodies. The slope farmland in the Three Gorges Reservoir area (TGRA) accounts for a high proportion (42\%) [3], and it overlaps with the heavy rain area in the Yangtze River Basin [4], resulting in serious soil erosion in the area. According to the Soil and Water Conservation Bulletin, soil erosion areas accounted for $32.93 \%$ of the total TGRA in 2019 [5]; the TGRA is a key national-level soil and water conservation area. Calcareous soil, accounting for $34.1 \%$ of the total area of the reservoir area [6], is one of the main soil types in the TGRA, and one of the soils with a high risk of loss. Calcareous soil on slope farmland is a main source of soil erosion in the reservoir area.

Excessive input of phosphorus via soil erosion is a key factor leading to eutrophication of water bodies [7-9]. There are two main transport mechanisms of phosphorus in slope farmland: one is the loss of particulate phosphorus via soil erosion, and the other is the loss of dissolved phosphorus via surface runoff and prompt subsurface flow. Studies have shown that the particulate phosphorus lost with soil erosion is the main form of phosphorus loss during migration, and its proportion can generally account for more than 
$80 \%$ of total phosphorus loss [3,10]. Phosphorus lost via soil erosion enters the water system and undergoes migration and transformation [11,12], resulting in reproduction of a large number of harmful algae and causing the eutrophication of water bodies. On the other hand, in the process of soil erosion, water, soil, and fertilizer are lost together, degrading soil quality [8] and declining the productivity of soil in the slope farmland; in order to maintain the level of productivity, a large number of chemical fertilizers are used, which will intensify the eutrophication of water bodies. Therefore, studying the fixation mechanism of phosphorus in the soil is of great significance to control the loss of phosphorus.

Phosphorus in the soil is mainly fixed by minerals in the soil [12]. Soil minerals as the main constituents of soil generally account for $95 \%$ to $98 \%$ of the soil mass. Studies have shown that in calcareous soil, calcium carbonate, as the main substrate for phosphorus, binds to form calcium-bound phosphorus to fix phosphorus [13-15]. Other studies have shown that physical clays in calcareous soil [16,17], especially the phyllosilicates [18], also have a strong effect of fixing phosphorus. The mineral composition of different particle size fractions varies greatly. Generally speaking, the minerals in the coarse fractions are mainly primary minerals (such as feldspar, calcite, muscovite, etc.), and in the fine fractions they are mainly clay minerals (such as kaolinite, montmorillonite, etc.) $[19,20]$, which make the fixing mechanism and phosphorus fractions differ in different particle size fractions of the soil [21].

At present, there are relatively few studies on the effect of the particle size and mineral composition of calcareous soils on slope farmland on phosphorus fixation, and understanding this effect will improve the management of phosphorus loss from such soils. The objectives of this study were to determine (1) the phosphorus fractions and mineral components in different particle size fractions of calcareous soil on slope farmland; (2) their adsorption properties for phosphorus; and (3) the effect of mechanical and mineral composition on phosphorus fixation.

\section{Materials and Methods}

\subsection{Study Area and Sampling}

The Xiangxi River is the largest tributary of the TGRA in Hubei Province [22], running through Xingshan County prior to flowing into the Yangtze River in the Zigui County of Yichang city (Figure 1). The main terrain of the Xiangxi River watershed is mountainous and hilly, representing a typical agroforestry complex in the TGRA. The Xiangxi River Basin is one of the rainfall centers in western Hubei, with an average annual rainfall of 900-1200 mm. Rainfall mostly occurs between April and September, accounting for about $70 \%$ of the total annual rainfall. There is a big difference in rainfall across different regions, years, and seasons, with more in the north than in the south and more in high mountainous areas than in low-lying areas. Furthermore, $41 \%, 28 \%, 26 \%$, and $5 \%$ of the total annual rainfall occurs in the summer, spring, autumn, and winter, respectively.

Test soils were taken from Chenjiawan ( $\left.31^{\circ} 7^{\prime} 21.25^{\prime \prime} \mathrm{N}, 110^{\circ} 47^{\prime} 58.93^{\prime \prime} \mathrm{E}\right)$, Jianyangping Village, Xingshan County, and the Xiangxi River Basin (Figure 1), belonging to the Lifangyan small watershed of the Gaolan River, a tributary of the Xiangxi River system. The slope of the planting area is generally about $10-20^{\circ}$, representing a typical slope farmland along the river bank of the Xiangxi River Basin in the TGRA. The main economic crops in Xingshan and Zigui County constitute citrus plants. The planting area of citrus in Chenjiawan is approximately 8 ha, accounting for $81 \%$ of the total planting area. Altitudes above $280 \mathrm{~m}$ represent the forest area, whereas those between 175 and $280 \mathrm{~m}$ represent the farming area, and those below $175 \mathrm{~m}$ represent the riparian zone. The slope characteristics of this area are fully representative of those seen in the Xiangxi River Basin. 


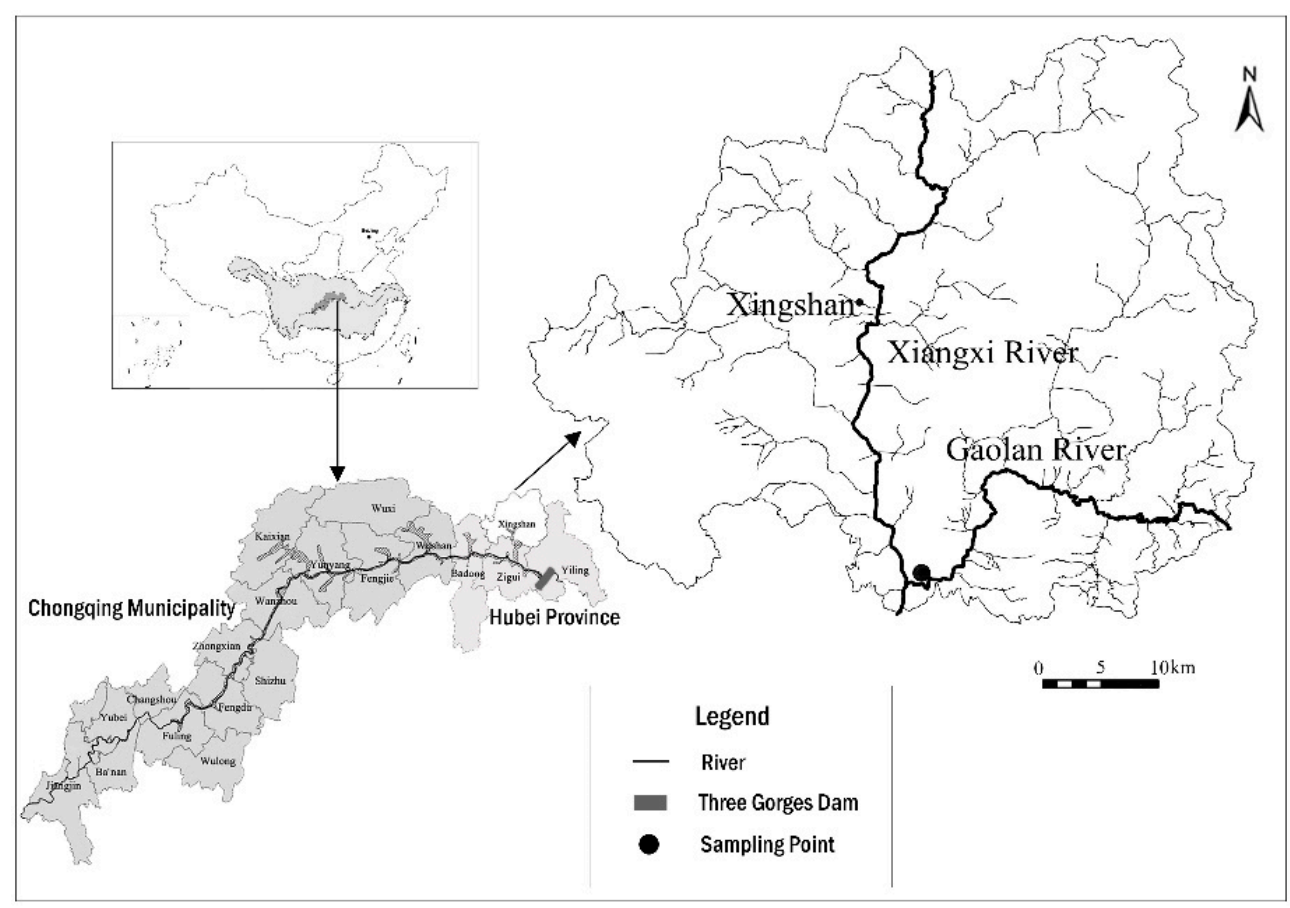

Figure 1. Location of sampling point in the Three Gorges Reservoir area.

The soil in this area constitutes brown calcareous soil developed from slope deposits of limestone parent material. According to the World Reference Base for Soil Resources (WRB) classification, the soil was calcaric. The soil samples were collected with a sampling depth of 0-20 cm. After being air dried, they were ground with a wooden hammer and passed through a $2 \mathrm{~mm}$ mesh sieve. The basic physical and chemical properties of the soil samples are shown in Table 1.

Table 1. The basic physical and chemical properties of the soil sample.

\begin{tabular}{ccccccccc}
\hline Sample & Slope $^{\circ}$ & $\begin{array}{c}\text { Bulk Density/ } \\
\left(\mathbf{g} \cdot \mathbf{c m}^{-\mathbf{3}} \mathbf{)}\right.\end{array}$ & $\begin{array}{c}\mathbf{p H} / \\
\mathbf{( 1 : 2 . 5 )}\end{array}$ & $\begin{array}{c}\text { OM/ } \\
\mathbf{( \% )}\end{array}$ & $\begin{array}{c}\mathrm{TN} / \\
\left(\mathbf{g} \cdot \mathbf{K g}^{-\mathbf{1}}\right)\end{array}$ & $\begin{array}{c}\mathrm{TP} / \\
\left(\mathbf{g} \cdot \mathbf{K g}^{-\mathbf{1}}\right)\end{array}$ & $\begin{array}{c}\text { Olsen-P/ } \\
\left(\mathbf{m g} \cdot \mathbf{K g}^{-\mathbf{1}}\right)\end{array}$ & $\begin{array}{c}\text { TK/ } \\
\left(\mathbf{g} \cdot \mathbf{K g}^{-\mathbf{1}} \mathbf{)}\right.\end{array}$ \\
\hline $\mathrm{A}$ & 10 & 1.36 & 7.64 & 1.51 & 1.41 & 0.88 & 48.75 & 15.21 \\
$\mathrm{~B}$ & 15 & 1.39 & 7.52 & 1.34 & 1.44 & 0.87 & 50.22 & 15.32 \\
\hline
\end{tabular}

$\mathrm{pH}$ : hydrogen ion concentration, OM: organic matter, TN: total nitrogen, TP: total phosphorus, Olsen-P: readily available phosphorus, TK: total potassium.

\subsection{Soil Aggregate Fractionation}

In this study, four particle sizes were determined according to the classification standard of the International Soil Association [23,24], namely, clay $(<2 \mu \mathrm{m})$, silt $(2-20 \mu \mathrm{m})$, fine sand $(20-200 \mu \mathrm{m})$, and coarse sand $(200-2000 \mu \mathrm{m})$. After the mixture of soil and water was fully dispersed ultrasonically, the soil samples were separated via a combination of wet sieving and sedimentation [23,25-27]. Specifically, about $600 \mathrm{~g}$ of the air-dried sample was mixed and soaked in $2 \mathrm{~L}$ of deionized water for $24 \mathrm{~h}$, before being subjected to ultrasonic vibration for $30 \mathrm{~min}$. Coarse sand was separated from the suspension via wet sieving. The sieved suspension containing the fine fractions was placed in a sedimentation bucket before being diluted to $21 \mathrm{~L}$. The sedimentation velocity of the clay and silt in still water was calculated according to Stokes' law (Equation (1)), and then the sedimentation times, $t_{1}$ and $t_{2}$, were calculated according to the sedimentation distance, $h$. Timing was initiated after the suspension was fully stirred. When the sedimentation time reached $t_{1}$, the siphon method was used to extract the suspension at a depth, $h$, below the liquid level. Extraction was completed when the liquid level dropped to $h$, then deionized water was added to achieve the original liquid level. This process was repeated several times until the upper 
layer was completely clarified. The siphoned suspension was precipitated and dried to reveal clay. When this procedure was applied at $t_{2}$, the soil sample siphoned out was silt. The remaining soil sample in the sedimentation bucket was fine sand. Each component was weighed after drying at $45^{\circ} \mathrm{C}$ to constant weight, and the proportion of each particle fraction was calculated. Three parallel tests were carried out at the same conditions, after which soil samples of the same particle size were mixed.

The relationship between the velocity and particle diameter is as follows [23]:

$$
v=\frac{\left(\rho_{s}-\rho_{l}\right) g X^{2}}{18 \eta}
$$

where $v$ is the velocity of fall, $X$ is the particle diameter, $\rho_{s}$ is the particle density, $\rho_{l}$ is the liquid density (water in this study), $g$ is the acceleration due to gravity, and $\eta$ is the fluid viscosity.

\subsection{Characterization of Soils}

Soil $\mathrm{pH}$ was measured in a 1:2.5 (wt.\%) ratio of soil to water. Organic matter (OM) was determined using the Mebius procedure [28] when heated with an electric hot plate (EG-35B). Total nitrogen (TN) was determined using the semi-micro Kjeldahl method [29] with a semi-automatic nitrogen analyzer (K9840), applied after heating concentrated sulfuric acid with the Graphite Digestion Apparatus (SH220N). Total phosphorus (TP) was determined by means of the ascorbic acid and ammonium molybdate blue method with an ultraviolet spectrophotometer (UV-2100) at $700 \mathrm{~nm}$ [30] after $\mathrm{HClO}_{4}-\mathrm{H}_{2} \mathrm{SO}_{4}$ digestion with the Graphite Digestion Apparatus (SH220N). Total potassium (TK) was determined via flame photometry with a flame photometer (PF640) after $\mathrm{NaOH}$ melting [31]. Available phosphorus (Olsen-P) was evaluated using a $0.5 \mathrm{M} \mathrm{NaHCO}_{3}$ solution ( $\mathrm{pH}$ 8.5) for the extraction [32] before determination by means of the ascorbic acid and ammonium molybdate blue method. Organic phosphorus (Org-P) was calculated using the ignition method with a high-temperature resistance furnace (KSY-6d-16) at $600^{\circ} \mathrm{C}$ after the extraction method with $0.2 \mathrm{M} 1 / 2 \mathrm{H}_{2} \mathrm{SO}_{4}$ [33]. Sequential fractionations of inorganic phosphorus (IP) were categorized into six types according to Jiang and $\mathrm{Gu}$ (Table 2) [34]: dicalcium phosphate $\left(\mathrm{Ca}_{2}-\mathrm{P}\right)$, octacalcium phosphate $\left(\mathrm{Ca}_{8}-\mathrm{P}\right)$, aluminum phosphate $(\mathrm{Al}-\mathrm{P})$, phosphate adsorbed on iron oxides (Fe-P), iron oxide occluded phosphate (O-P), and decacalcium phosphates $\left(\mathrm{Ca}_{10}-\mathrm{P}\right)$.

Table 2. A sequential fractionation method for calcareous soils by Jiang and Gu (1989) [34].

\begin{tabular}{|c|c|c|c|}
\hline Step & P Fractions & Extractants, $\mathrm{pH}$ and Dosage & Shaking Time \\
\hline $1^{\mathrm{a}}$ & $\mathrm{Ca}_{2}-\mathrm{P}$ & $0.25 \mathrm{M} \mathrm{NaHCO}_{3} \mathrm{pH}=7.5,50 \mathrm{~mL}$ & $1 \mathrm{~h}^{\mathrm{b}}$ \\
\hline $2^{c}$ & $\mathrm{Ca}_{8}-\mathrm{P}$ & $0.5 \mathrm{M} \mathrm{NH}_{4} \mathrm{OAc} \mathrm{pH}=4.2,50 \mathrm{~mL}$ & $4 \mathrm{~h}$ stand, $1 \mathrm{~h} \mathrm{~b}$ \\
\hline $3^{d}$ & Al-P & $0.5 \mathrm{M} \mathrm{NH}_{4} \mathrm{~F} \mathrm{pH}=8.2,50 \mathrm{~mL}$ & $1 \mathrm{~h}$ be \\
\hline $4^{\mathrm{d}}$ & $\mathrm{Fe}-\mathrm{P}$ & $0.1 \mathrm{M} \mathrm{NaOH}-0.1 \mathrm{M} \mathrm{Na}_{2} \mathrm{CO}_{3}, 50 \mathrm{~mL}$ & $2 \mathrm{~h}, 16 \mathrm{~h}$ stand, $2 \mathrm{~h}$ fg \\
\hline $5^{d}$ & $\mathrm{O}-\mathrm{P}$ & $\begin{array}{c}0.3 \mathrm{M} \mathrm{Na}_{3} \mathrm{CA} 40 \mathrm{~mL}, \mathrm{Na}_{2} \mathrm{~S}_{2} \mathrm{O}_{4}, 1 \mathrm{~g} \text { and } 0.5 \mathrm{M} \mathrm{NaOH} \\
10 \mathrm{~mL}\end{array}$ & $\begin{array}{l}\text { mix at } 80-90{ }^{\circ} \mathrm{C} \text {, centrifuge }{ }^{\mathrm{b}}, \text { heat with } 10 \mathrm{~mL} \\
\text { mixture }\left(\mathrm{V}_{\mathrm{H} 2 \mathrm{SO} 4}: \mathrm{V}_{\mathrm{HClO} 4}: \mathrm{V}_{\mathrm{HNO} 3}=1: 2: 7\right)\end{array}$ \\
\hline 6 & $\mathrm{Ca}_{10}-\mathrm{P}$ & $0.5 \mathrm{M} 1 / 2 \mathrm{H}_{2} \mathrm{SO}_{4} 50 \mathrm{~mL}$ & $1 \mathrm{~h}$ \\
\hline
\end{tabular}

\subsection{Mineralogical Analysis}

The total amount of each soil elements was measured using an X-ray fluorescence spectrometer (Zetium), according to standard JY/T 016-1996. The detection conditions were as follows: voltage, $30-60 \mathrm{kV}$; current, $50-100 \mathrm{~mA}$.

Fourier-transform infrared spectroscopy (FTIR) analysis was conducted using a Thermo Nicolet 6700 FTIR Spectrometer. First, $1 \mathrm{mg}$ of the sample was mixed and ground with $100 \mathrm{mg}$ of $\mathrm{KBr}$ in an agate mortar before being pressed into a disc. The infrared spectrum was collected at a resolution of $4 \mathrm{~cm}^{-1}$ in the range $4000-400 \mathrm{~cm}^{-1}$ [35]. 
The mineralogy of selected fractions was determined by X-ray diffraction (Bruker D8 Advance) analysis between 5-80 . Samples were scanned at $40 \mathrm{kV}$ and $50 \mathrm{~mA}$ using $\mathrm{Cu}-\mathrm{K} \alpha$ radiation $[35,36]$.

\subsection{Sorption Isotherm Measurements}

The sorption of phosphorus (added as $\mathrm{KH}_{2} \mathrm{PO}_{4}$ ) was studied by shanking aqueous suspensions with $1.00 \mathrm{~g}$ of the sample placed in $100 \mathrm{~mL}$ Erlenmeyer flasks containing $50 \mathrm{~mL}$ of $\mathrm{KH}_{2} \mathrm{PO}_{4}$ solution. The initial P concentrations were $0,5,10,20,30,40,50,60$, $70,80,90$, and $100 \mathrm{mg} \cdot \mathrm{L}^{-1}$, respectively. Three drops of chloroform were added to inhibit microbial activity. After $24 \mathrm{~h}$ of equilibration with an oscillation frequency of $200 \mathrm{rpm}$ at $25 \pm 1^{\circ} \mathrm{C}$, the solution was centrifuged at a rotational speed of $4000 \mathrm{rpm}$ for $10 \mathrm{~min}$. The $\mathrm{P}$ concentration in the supernatant was determined, and the amount of phosphorus adsorbed by the soil was calculated. All the tests were repeated three times, with results presented as the mean.

The Langmuir isotherm and Freundlich isotherm models were applied to evaluate adsorption, as shown in the following equations:

$$
\begin{gathered}
q_{e L}=\frac{q_{m} K_{L} C_{e}}{1+K_{L} C_{e}} \\
q_{e K}=K_{F} C_{e}^{1 / n}
\end{gathered}
$$

where $q_{e}$ is the amount of phosphorus adsorption $\left(\mathrm{mg} \cdot \mathrm{g}^{-1}\right)$ at equilibrium, $C_{e}$ is the dissolved phosphorus concentration in the solution $\left(\mathrm{mg} \cdot \mathrm{L}^{-1}\right)$ at equilibrium, $q_{m}$ is the maximum amount of phosphorus adsorption $\left(\mathrm{mg} \cdot \mathrm{g}^{-1}\right), K_{L}$ is the Langmuir adsorption coefficient, $K_{F}$ is the Freundlich adsorption coefficient, and $n$ is a constant determined via experiments.

\subsection{Data Processing and Statistical Analysis}

Weathering indices, such as the silica-alumina ratio and the silica-sesquioxide ratio [37] (given in the equations below) were calculated to estimate the degree of weathering of the soil sample.

$$
\begin{gathered}
\text { silica - alumina ratio }=\frac{\mathrm{SiO}_{2}}{\mathrm{Al}_{2} \mathrm{O}_{3}} \text { sa value }=\frac{\mathrm{SiO}_{2}}{\mathrm{Al}_{2} \mathrm{O}_{3}} \\
\text { silica }- \text { sesquioxide ratio }=\frac{\mathrm{SiO}_{2}}{\mathrm{Al}_{2} \mathrm{O}_{3}+\mathrm{Fe}_{2} \mathrm{O}_{3}}
\end{gathered}
$$

Origin Pro 8.5 was used for adsorption isotherm simulations.

Statistical tests for multivariable correlation matrix calculation were conducted using software SPSS 18, and the selected level of significance was $p<0.05$ [38]. Each index was measured three times. The Topas software package was used for mineral content analysis.

\section{Results}

\subsection{Particle Size Distribution}

The soil samples were separated on the basis of particle size (Table 3). From the results of particle size analysis, it could be seen that the highest proportion of Sample A was fine sand (39.5\%), followed by silt (37.2\%) and coarse sand $(19.8 \%)$, and the lowest proportion was clay particle $(3.4 \%)$. In Sample B, the order of proportion of fractions was fine sand $(39.8 \%)>$ silt $(37.1 \%)>$ coarse sand $(19.8 \%)>$ clay $(3.3 \%)$. According to the international soil texture classification standard [23], sample A and B were all Sandy Loam. 
Table 3. Particle-size distribution of the soil samples.

\begin{tabular}{cccc}
\hline Fractions & Particle Size/ $\boldsymbol{\mu m}$ & Sample A & Sample B \\
\hline Clay & $<2$ & $3.42 \pm 0.31 \mathrm{~d}$ & $3.26 \pm 0.77 \mathrm{~d}$ \\
Silt & $2-20$ & $37.20 \pm 1.21 \mathrm{~b}$ & $37.13 \pm 1.34 \mathrm{~b}$ \\
Fine Sand & $20-200$ & $39.55 \pm 0.16 \mathrm{a}$ & $39.84 \pm 0.48 \mathrm{a}$ \\
Coarse Sand & $200-2000$ & $19.82 \pm 1.26 \mathrm{c}$ & $19.76 \pm 1.27 \mathrm{c}$ \\
\hline
\end{tabular}

Different letters mean significant differences between sample plots in four particle size fractions $(p<0.05)$.

\subsection{Distribution of Phosphorus}

Figure 2 shows the fractionation of various phosphorus forms $\left(\mathrm{Ca}_{2}-\mathrm{P}, \mathrm{Ca}_{8}-\mathrm{P}, \mathrm{Ca}_{10}-\mathrm{P}\right.$, Al-P, Fe-P, O-P, and Org-P) in the soil samples for different particle sizes. There were little differences in contents of $P$ between sample A and B. Among the fractions investigated, the highest TP content was found in fine sand, followed by silt, coarse sand, and clay. Inorganic $\mathrm{P}(\mathrm{IP})$ was the main component of TP in all fractions, accounting for $52.48-87.95 \%$, and its proportion increased with particle size.

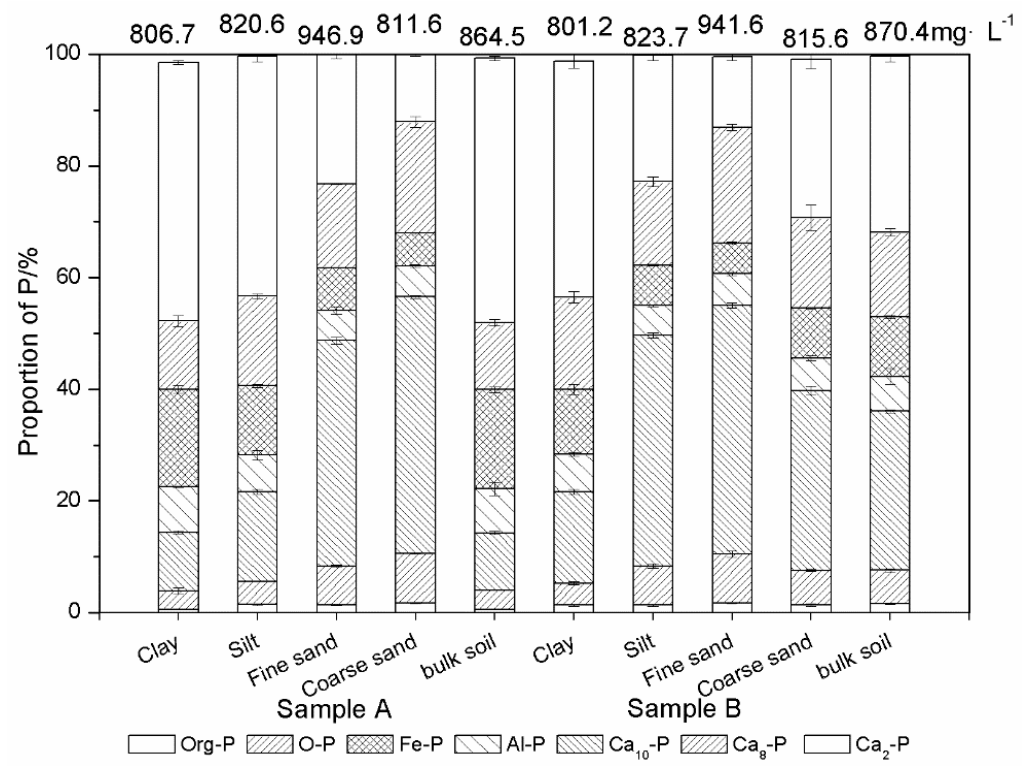

Figure 2. Distribution of various forms of $\mathrm{P}$ (expressed as percentage of the total) in each particle size fraction ( $\mathrm{Ca}_{2}-\mathrm{P}$ : dicalcium phosphate, $\mathrm{Ca}_{8}-\mathrm{P}$ : octacalcium phosphate, $\mathrm{Ca}_{10}-\mathrm{P}$ : decacalcium phosphates, Al-P: aluminum phosphate, Fe-P: phosphate adsorbed on iron oxides, O-P: iron oxide occluded phosphate, Org-P: Organic phosphorus).

Similar to the distribution of phosphorus in other calcareous soils [39], calcium phosphorus (Ca-P) was the main form of IP in this sample, especially in the coarser fractions, accounting for $55 \%$ and $49 \%$ of TP in coarse sand and fine sand, respectively. The level of Ca-P was relatively lower in silt and clay, accounting for $21 \%$ and $14 \%$, respectively, decreasing with particle size. For each particle size fraction, $\mathrm{Ca}_{10}-\mathrm{P}$ was the main form of Ca-P, accounting for $45 \%$ and $41 \%$, respectively, of TP in coarse and fine sand, and $16 \%$ and $10 \%$, respectively, in silt and clay. The content of $\mathrm{Ca}_{8}-\mathrm{P}$ was lower than that of $\mathrm{Ca}_{10}-\mathrm{P}$, with approximately one-fifth of the content for sand and one-third of the content for clay and silt. The lowest content was represented by $\mathrm{Ca}_{2}-\mathrm{P}$, accounting for about $1 \%$ of TP in all particle size fractions.

There was little difference in the contents of O-P and Al-P across the sample, accounting for $12-20 \%$ and $5.4-8 \%$ of TP, respectively. On the other hand, the content of Fe-P varied greatly, decreasing approximately threefold from clay to coarse sand. 


\subsection{Mineralogical Analysis of Soil Samples}

\subsubsection{Chemical Composition Analyses}

The main chemical components in the various soil samples were $\mathrm{SiO}_{2}(>36 \%), \mathrm{Al}_{2} \mathrm{O}_{3}$ (8.9-22.2\%), $\mathrm{CaO}(3.6-24.3 \%)$, and $\mathrm{Fe}_{2} \mathrm{O}_{3}(2.5-9.1 \%)$ (Table 4), along with minor levels of $\mathrm{MgO}, \mathrm{K}_{2} \mathrm{O}, \mathrm{TiO}_{2}$, and $\mathrm{Na}_{2} \mathrm{O}$. The highest content of $\mathrm{P}_{2} \mathrm{O}_{5}$ was found in the fine sand $(0.26 \%)$, whereas the content of other fractions was around $0.2 \%$. The content of $\mathrm{SiO}_{2}$ was the lowest in coarse sand, and the content of $\mathrm{Al}_{2} \mathrm{O}_{3}$ gradually decreased with an increase in particle size. In contrast, the contents of $\mathrm{CaO}$ and $\mathrm{Fe}_{2} \mathrm{O}_{3}$ increased with particle size. The content of aluminosilicate minerals decreased, but the content of carbonate minerals (such as calcite and dolomite) increased with an increase in the particle size.

Table 4. Chemical composition of different particle-size fractions (\%).

\begin{tabular}{cccccccccc}
\hline Sample & Fractions & $\mathbf{S i O}_{\mathbf{2}}$ & $\mathbf{A l}_{\mathbf{2}} \mathbf{O}_{\mathbf{3}}$ & $\mathbf{C a O}$ & $\mathbf{F e}_{\mathbf{2}} \mathbf{O}_{\mathbf{3}}$ & $\mathbf{M g O}$ & $\mathbf{K}_{\mathbf{2}} \mathbf{O}$ & $\mathbf{P}_{\mathbf{2}} \mathbf{O}_{\mathbf{5}}$ & $\mathbf{L . O}_{\mathbf{O}} \mathbf{I a}$ \\
\hline \multirow{4}{*}{$\mathrm{A}$} & Bulk Soil & 48.19 & 15.08 & 10.08 & 5.31 & 2.48 & 1.97 & 0.23 & 14.99 \\
& Clay & 46.09 & 22.17 & 2.65 & 8.94 & 2.34 & 2.69 & 0.21 & 13.33 \\
& Silt & 49.03 & 18.19 & 5.78 & 6.84 & 2.14 & 2.45 & 0.21 & 13.9 \\
& Fine Sand & 50.14 & 14.09 & 10.1 & 4.87 & 2.96 & 1.82 & 0.26 & 13.97 \\
& Coarse Sand & 36.85 & 8.94 & 24.33 & 2.65 & 3.25 & 1.31 & 0.2 & 20.98 \\
\hline \multirow{3}{*}{ B } & Bulk Soil & 48.92 & 14.87 & 10.65 & 5.21 & 2.55 & 2.12 & 0.24 & 15.32 \\
& Clay & 46.31 & 22.52 & 2.55 & 9.06 & 2.44 & 2.63 & 0.22 & 13.15 \\
& Silt & 48.65 & 18.04 & 5.66 & 6.75 & 2.13 & 2.54 & 0.22 & 13.87 \\
& Fine Sand & 50.22 & 14.18 & 11.21 & 4.98 & 3.18 & 1.78 & 0.26 & 14.09 \\
& Coarse Sand & 36.98 & 9.03 & 24.23 & 2.47 & 3.28 & 1.32 & 0.21 & 20.88 \\
\hline
\end{tabular}

L.O.Ia: loss on ignition; the amount that the sample lost on ignition at $2000{ }^{\circ} \mathrm{C}$, usually including $\mathrm{H}_{2} \mathrm{O}$ and $\mathrm{CO}_{2}$.

\subsubsection{X-ray Diffraction Spectra Analyses}

Figure 3 shows the XRD patterns of different particle size fractions. In the bulk soil samples, quartz, muscovite, dolomite, kaolinite, calcite, albite, and orthoclase were present. Through semi-quantitative calculation of the mineral components using Topas (Table 5), it was found that they varied greatly across particle size fractions, whereas they varied little across samples. Quartz existed in all fractions, but the distributions were uneven, accounting for $11.82 \%$ in clay in sample A and $11.56 \%$ in sample B, but exceeding $20 \%$ in the other fractions, especially sand, where its content exceeded $35 \%$. Since quartz is the most stable primary mineral with strong weathering resistance [40], it is mainly found in sand and silt.

Muscovite was the second most abundant mineral in the bulk soil after quartz, whereby it was also found in all particle size fractions, primarily concentrated in silt and fine sand, where its content was approximately $30 \%$. It was also the main mineral in clay, with a content of $21.11 \%$, but its content in coarse sand was only $12.74 \%$. Dolomite was the third most abundant mineral in the bulk soil. It was distributed across all particle size fractions, but not uniformly, with high content in the coarse fractions and low content in the fine fractions. In both coarse sand and fine sand, the content of dolomite accounted for about one-fourth of the mineral composition, whereas its content in clay and silt was notably lower at $1.05 \%$ and $2.34 \%$, respectively.

Kaolinite is a layered silicate clay mineral, which was found in clay, silt, and fine sand, but no characteristic peak of kaolinite was identified in coarse sand. Its content accounted for $62.52 \%$ and $32.97 \%$ in clay and silt, respectively. The distribution of kaolinite was clearly enriched in the fine fractions, conforming to the general distribution law of secondary clay minerals [40]. The content of calcite decreased rapidly with particle size, accounting for $24.21 \%$ of coarse sand, whereas its content in other particle size fractions was lower than $8 \%$. The contents of albite and orthoclase were low, and their characteristic peaks were not found in clay. 


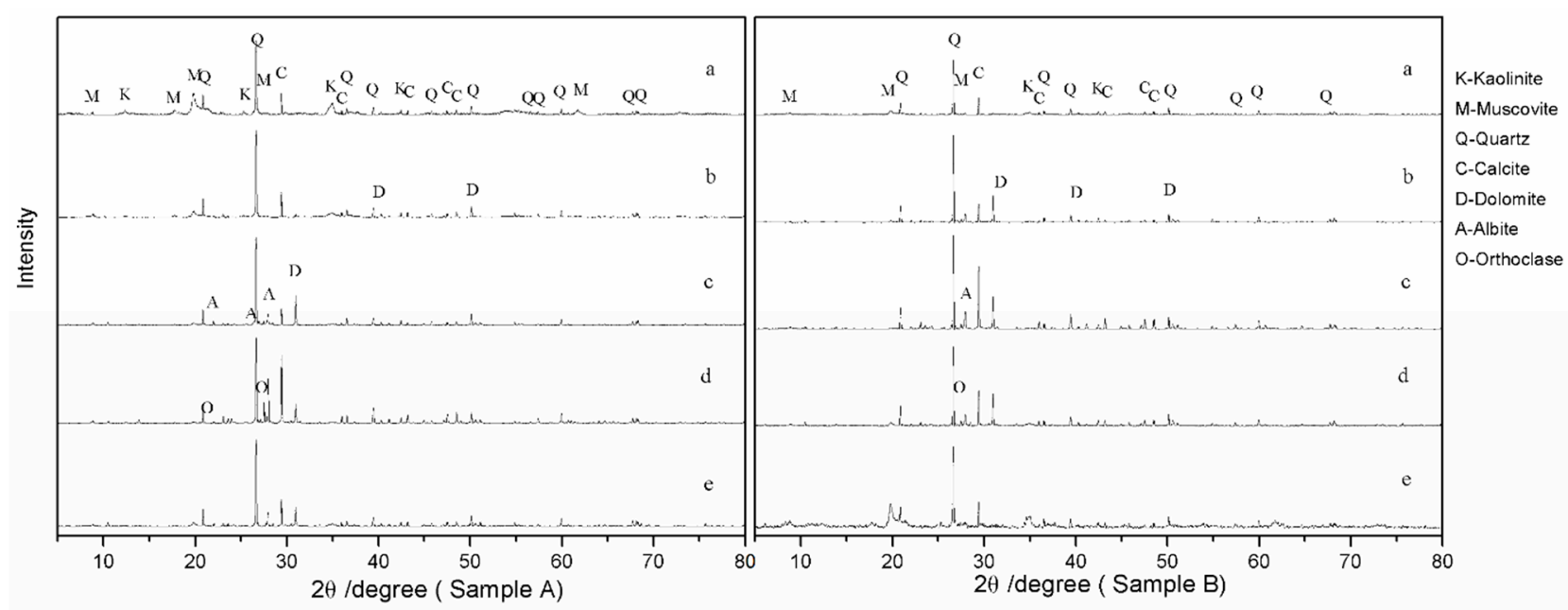

Figure 3. XRD patterns of different particle-size fractions ( $\mathrm{a}-$ Clay, b-Silt, $\mathrm{c}$-Fine Sand, $\mathrm{d}-$ Coarse Sand, e-Bulk Soil).

Table 5. Mineral concentration of different particle-size fractions (\%).

\begin{tabular}{ccccccccc}
\hline Sample & Fractions & Quartz & Muscovite & Dolomite & Kaolinite & Calcite & Albite & Orthoclase \\
\hline \multirow{4}{*}{ A } & Bulk Soil & 31.01 & 25.53 & 16.52 & 14.04 & 10.38 & 1.42 & 1.21 \\
& Clay & 11.82 & 21.11 & 1.65 & 62.52 & 2.08 & 0 & 0 \\
& Silt & 24.93 & 33.28 & 6.34 & 25.97 & 6.02 & 1.65 & 1.18 \\
& Fine Sand & 35.07 & 24.77 & 25.43 & 1.65 & 9.65 & 1.19 & 1.27 \\
& Coarse Sand & 35.23 & 12.74 & 24.01 & 0 & 24.21 & 2.24 & 1.97 \\
\hline \multirow{4}{*}{ B } & Bulk Soil & 30.26 & 25.61 & 16.88 & 13.43 & 11.12 & 1.26 & 1.09 \\
& Clay & 11.56 & 21.64 & 1.43 & 63.68 & 1.44 & 0 & 1.82 \\
& Silt & 23.67 & 33.93 & 6.02 & 25.75 & 6.62 & 1.43 \\
& Fine Sand & 35.33 & 24.63 & 25.02 & 1.82 & 9.86 & 1.08 & 1.32 \\
\hline
\end{tabular}

\subsubsection{Fourier-Transform Infrared (FT-IR) Spectra Analyses}

Figure 4 shows the infrared absorption spectrum of each particle size fraction. The band at $3697 \mathrm{~cm}^{-1}$ was assigned to the stretching vibration of a hydroxyl group (-OH) on the octahedral sheet in kaolinite [41,42]. It could be obviously seen in the spectra of clay, silt, and fine sand, but not in that of coarse sand. The band at $3620 \mathrm{~cm}^{-1}$ was assigned to the stretching vibrations of inner hydroxyl groups, found between the tetrahedral and octahedral sheets $[42,43]$. The intensity of this band decreased and broadened in coarse sand compared to other particle fractions. The $\mathrm{Si}-\mathrm{O}$ in-plane stretching vibration band of kaolinite also appeared near $1032 \mathrm{~cm}^{-1}[41,44]$. The $\mathrm{Al}_{2} \mathrm{OH}$ bending bands of silicate mineral near $913 \mathrm{~cm}^{-1}$ were a function of inner $\mathrm{OH}$ group vibrations $[41,45]$. The absorption bands near 3430 and $1631 \mathrm{~cm}^{-1}$ were due to the $\mathrm{H}-\mathrm{O}-\mathrm{H}$ stretching and bending vibrations of absorbed water, respectively [41], appearing in all particle-size fractions.

The band at $1430 \mathrm{~cm}^{-1}$ was assigned to the asymmetric stretching vibration of C-O groups, representing the characteristic absorption peak of carbonate minerals $[46,47]$. The band at $875 \mathrm{~cm}^{-1}$ was attributed to the out-of-plane bending vibration of $\mathrm{CO}_{3}{ }^{2-}$ [48]. On the other hand, the in-plane bending vibration at $712 \mathrm{~cm}^{-1}$ and $729 \mathrm{~cm}^{-1}$ allowed for the distinguishing of calcite and dolomite, respectively [48,49]. Bands at $2520 \mathrm{~cm}^{-1}$ (combined $\mathrm{CO}_{3}{ }^{2-}$ out-of-plane and in-plane bending vibration) and $1799 \mathrm{~cm}^{-1}$ (combined $\mathrm{CO}_{3}{ }^{2-}$ symmetrical stretching and in-plane bending vibration) [47] could also be observed in silt and sand. The sharp double bands at 799 and $779 \mathrm{~cm}^{-1}$ appeared in all particle size fractions, representing characteristic peaks of quartz attributed to the symmetrical stretching vibrations of the $\mathrm{Si}-\mathrm{O}$ bonds [48]. On the other hand, the bands at 1164 and $1082 \mathrm{~cm}^{-1}$ were attributed to the nonsymmetrical stretching vibrations of the Si-O bonds [49]. The 
band near $646 \mathrm{~cm}^{-1}$, characteristic of feldspars [49,50], was present in silt and sand, but not in clay. The bands near 753 and $695 \mathrm{~cm}^{-1}$ were attributed to the vertical vibrations of the hydroxyl groups on the surface of kaolinite [49]. The band near $530 \mathrm{~cm}^{-1}$ was due to the stretching vibration of the Si-O-Al group [42]. The bands near 470 and $430 \mathrm{~cm}^{-1}$ were assigned to Si-O-Si bending vibrations [42].

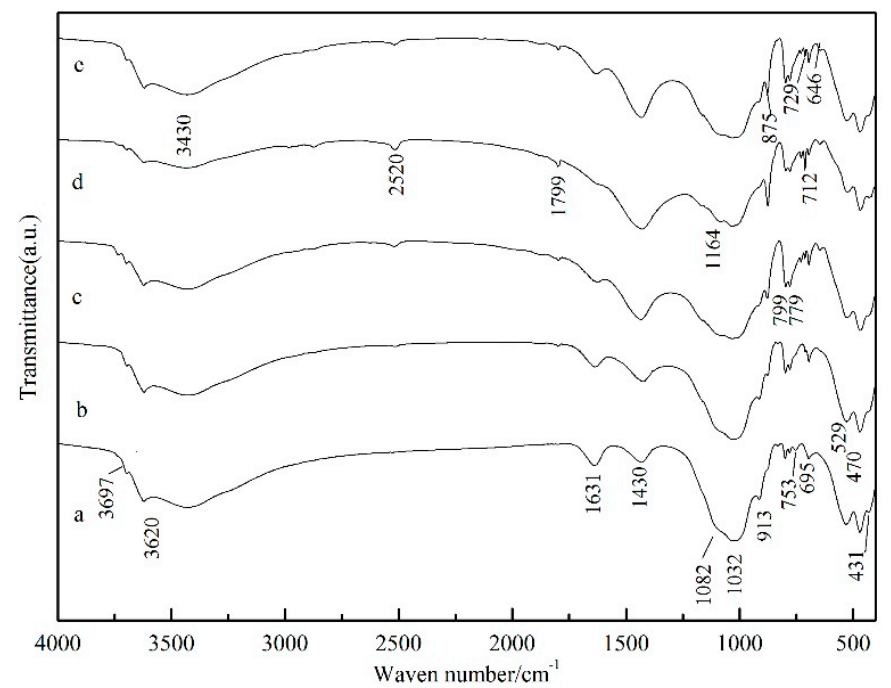

Figure 4. FT-IR spectra of different particle-size fractions ( $a-C l a y, b-S i l t, c-F i n e ~ S a n d, d-C o a r s e$ Sand, e-Bulk Soil).

\subsection{Phosphorus Equilibrium Adsorption}

Figure 5 shows the phosphorus adsorption curve of different particle size fractions. There was little difference between the bulk soils. The adsorption of clay with respect to phosphorus increased very rapidly, while that of the other three fractions increased relatively slowly. With increasing initial concentration, the order of adsorption of different particle size fractions was always clay $>$ silt $>$ fine sand $>$ coarse sand. At a higher initial concentration, the adsorption of different particle size samples varied more. For example, at the initial concentration of $30 \mathrm{mg} \cdot \mathrm{L}^{-1}$, the adsorption of clay was $0.577 \mathrm{mg} \cdot \mathrm{g}^{-1}$, while those of silt, fine sand, and coarse sand were $0.224,0.155$, and $0.094 \mathrm{mg} \cdot \mathrm{g}^{-1}$, respectively. The adsorption capacity of clay was, thus, far greater than that of other fractions (sixfold greater than that of coarse sand).

Table 6 shows the parameters of the Langmuir and Freundlich isotherm models. The constant, $n$, of the Freundlich isotherm curve equation did not change much, while the $K_{F}$ value (indicating the adsorption per unit concentration) decreased with an increase in particle size. The maximum adsorption $\left(\mathrm{q}_{\mathrm{m}}\right)$ of variation fractions was as follows: clay $\left(0.900 \mathrm{mg} \cdot \mathrm{g}^{-1}\right)>\operatorname{silt}\left(0.384 \mathrm{mg} \cdot \mathrm{g}^{-1}\right)>$ fine sand $\left(0.304 \mathrm{mg} \cdot \mathrm{g}^{-1}\right)>$ coarse sand $\left(0.204 \mathrm{mg} \cdot \mathrm{g}^{-1}\right)$.

\subsection{Correlation Analysis}

Table 7 shows the results of Pearson's correlation of phosphorus and its adsorption to the level of soil minerals in different particle size fractions. $\mathrm{Ca}_{8}-\mathrm{P}, \mathrm{Ca}_{10}-\mathrm{P}$, and $\mathrm{Ca}-\mathrm{P}$ were significantly positively correlated with dolomite $(p<0.01)$. Fe and $K_{F}$ were significantly positively correlated with kaolinite $(p<0.01) . K_{L}$ was significantly positively correlated with kaolinite $(p<0.05)$. 


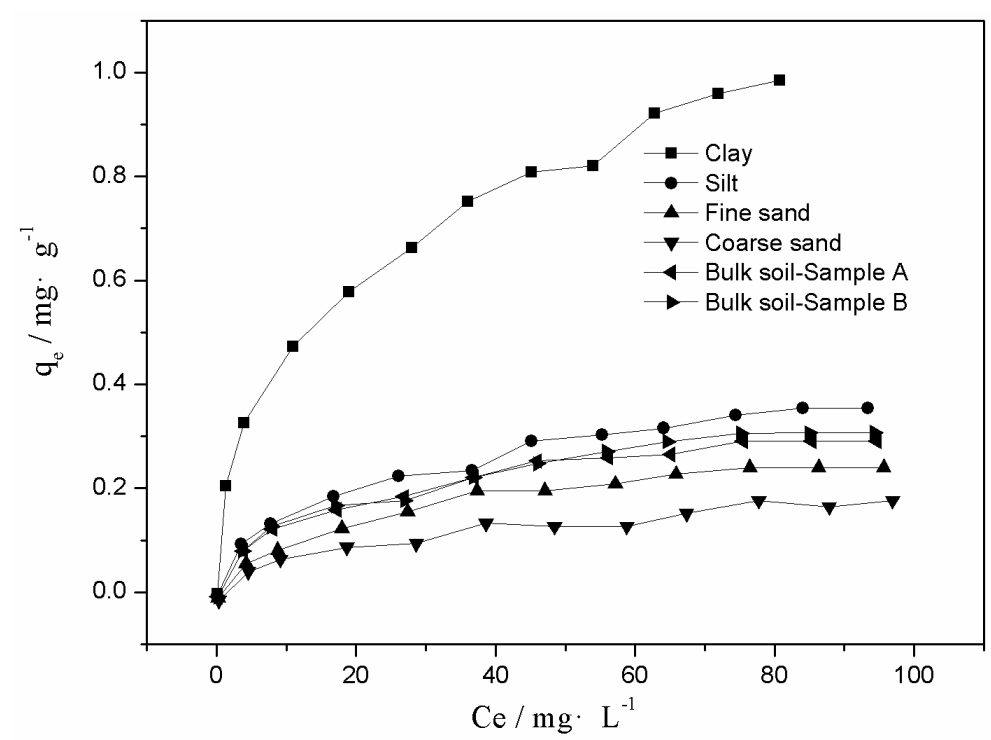

Figure 5. Adsorption curves of different particle-size fractions at different initial P concentration (Ce: equilibrium concentration of the solution, $\mathrm{q}_{\mathrm{e}}$ : phosphorus adsorption quantity of the sample under equilibrium conditions).

Table 6. Parameters in Langmuir and Freundlich isotherm models.

\begin{tabular}{|c|c|c|c|c|c|c|}
\hline \multirow{2}{*}{ Fractions } & \multicolumn{3}{|c|}{ Langmuir Parameters } & \multicolumn{3}{|c|}{ Freundlich Parameters } \\
\hline & $\mathrm{q}_{\mathrm{m}} / \mathrm{mg} \cdot \mathrm{g}^{-1}$ & $K_{L}$ & $\mathrm{r}^{2}$ & $K_{F}$ & $n$ & $\mathbf{r}^{2}$ \\
\hline Clay & 0.900 & 0.214 & 0.870 & 0.191 & 2.66 & 0.998 \\
\hline Silt & 0.384 & 0.091 & 0.871 & 0.056 & 2.41 & 0.994 \\
\hline Fine Sand & 0.304 & 0.042 & 0.932 & 0.029 & 2.06 & 0.980 \\
\hline Coarse Sand & 0.204 & 0.048 & 0.920 & 0.021 & 2.12 & 0.974 \\
\hline Bulk Soil-Sample A & 0.349 & 0.075 & 0.889 & 0.050 & 2.42 & 0.989 \\
\hline Bulk Soil-Sample B & 0.351 & 0.074 & 0.889 & 0.049 & 2.40 & 0.985 \\
\hline
\end{tabular}

Table 7. Correlation matrix of phosphorus and adsorption to soil mineral.

\begin{tabular}{|c|c|c|c|c|c|c|c|c|c|c|c|c|}
\hline & $\mathrm{Ca}_{2}-\mathrm{P}$ & $\mathrm{Ca}_{8}-\mathrm{P}$ & $\mathrm{Ca}_{10}-\mathrm{P}$ & Al-P & Fe-P & O-P & Org-P & Ca-P & TP & $\mathrm{q}_{\mathrm{m}}$ & $K_{L}$ & $K_{F}$ \\
\hline Kaolinite & $-0.908 *$ & $-0.948 *$ & $-0.957 *$ & 0.864 & $0.963 * *$ & 0.595 & $0.902 *$ & $-0.961 * *$ & $-0.939 *$ & -0.521 & 0.940 * & $0.962 * *$ \\
\hline Muscovite & 0.038 & -0.372 & -0.242 & 0.469 & 0.251 & 0.745 & 0.533 & -0.252 & -0.016 & 0.606 & -0.003 & -0.057 \\
\hline Quartz & 0.935 * & $0.918^{*}$ & $0.931 *$ & -0.855 & $-0.965^{* *}$ & -0.527 & -0.871 & 0.936 * & $0.922 *$ & 0.530 & $-0.962^{* *}$ & $-0.978^{* *}$ \\
\hline Calcite & 0.669 & 0.794 & 0.694 & $-0.940 *$ & -0.850 & -0.726 & $-0.909 *$ & 0.709 & 0.521 & -0.196 & -0.701 & -0.636 \\
\hline Dolomite & 0.701 & $0.989 * *$ & $0.994^{* *}$ & -0.792 & -0.851 & -0.826 & $-0.938 *$ & $0.994^{* *}$ & 0.949 * & 0.495 & -0.749 & -0.805 \\
\hline Albite & 0.758 & 0.575 & 0.477 & $-0.879 *$ & -0.816 & -0.343 & -0.708 & 0.498 & 0.338 & -0.268 & -0.765 & -0.655 \\
\hline Orthoclase & 0.762 & 0.936 * & 0.873 & $-0.961 * *$ & $-0.932 *$ & -0.799 & $-0.990 * *$ & 0.884 * & 0.744 & 0.087 & -0.801 & -0.779 \\
\hline
\end{tabular}

${ }^{*}$. Mean correlation is significant at $p<0.05 .{ }^{* *}$. Mean correlation is significant at $p<0.01$.

\section{Discussion}

The soil clay content in the TGRA is very low (Table 3) due to the selective migration of fine fractions. An investigation [51] showed that the critical shear stress and critical flow force increase with increased particle size, whereby fine fractions transfer more quickly than other fractions in the process of loss [52], resulting in a lower proportion of finer fractions and a greater proportion of coarser fractions in the residual soil. In addition, the adhesion and deposition of organic matter in clay could reduce the risk of clay loss [53]. However, this phenomenon was not present in the study area, resulting in a high risk of clay loss. Generally speaking, the selective migration of fine fractions occurs continuously during the long-term cultivation process on slope farmland [54,55]. At the same time, the low organic matter content in the soil aggravates the loss of fine fractions. Generally, under the combined action of these two factors, the clay content is low and the silt content is high $[39,53]$. 
The contents of $\mathrm{Ca}_{10}-\mathrm{P}$ were higher than those of $\mathrm{Ca}_{2}-\mathrm{P}$ and $\mathrm{Ca}_{8}-\mathrm{P}$ (Figure 2), as the latter are easily absorbed and utilized by plants $[34,56,57]$, whereas unstable phosphorus forms (such as $\mathrm{Ca}_{2}-\mathrm{P}$ ) are transformed into stable phosphorus forms (such as $\mathrm{Ca}_{10}-\mathrm{P}$ ) during inorganic phosphorus transformation [58,59].

The smaller the silica-alumina ratio and the silica-sesquioxide ratio, the higher the weathering degree of the soil [19]. Generally speaking, clay soil with a low silica-sesquioxide ratio has a stronger ability to adsorb and withhold phosphorus than sandy soil [60]. In this study, the silica-alumina ratio and silica-sesquioxide ratio of bulk soil sample A were 5.43 and 4.66, respectively, and those of bulk soil sample B were 5.59 and 4.80, respectively, indicating that the weathering intensity in the study area was weak, resulting in a lower ability of soil to adsorb phosphorus (Figure 5).

Through a comprehensive analysis of mineral components (Table 5) on the basis of XRD patterns (Figure 3) and FT-IR spectra (Figure 4), the contents of quartz, muscovite, calcite, etc., could be estimated as a function of their phase characteristics and infrared characteristics. The bands near $3697 \mathrm{~cm}^{-1}$ and $646 \mathrm{~cm}^{-1}$ (Figure 4) were consistent with estimative minerals data (Table 5), confirming that there was no kaolinite in coarse sand and no feldspars (albite and orthoclase) in clay.

The main components of clay and silt were kaolinite and muscovite (Table 5), respectively. The main mineral components of clay and silt were similar, but the adsorption capacity of clay with respect to phosphorus depended on the specific surface area of these minerals [61]. As clay particles are smaller than silt particles, their specific surface area is larger [62], providing more sites for the adsorption of phosphorus. Accordingly, the adsorption capacity of clay was 2-3-fold that of silt, depending on the initial concentration (Figure 4). The main mineral components in sand were quartz, dolomite, and calcite (Table 5), unlike clay and silt. In contrast to other minerals, $\mathrm{Al}^{3+}$ exists on the edge group Al-OH group of kaolinite [63], facilitating the exchange of phosphate ions on a relatively short timescale. Griffin [64] found that, during the reaction of phosphate and calcite, adsorption only occurred at specific positions, thereby forming surface clusters of phosphate ions, leading to the growth of hydroxyapatite crystals. However, the sites available for adsorption only account for 5\% of the particle surface [64]. Quartz has a relatively smooth surface with fewer voids and fewer adsorption sites, thus resulting in a lower phosphorus adsorption capacity than calcite [65]. As such, the adsorption capacity of coarse sand was far weaker than that of clay. The mineral compositions of fine sand and coarse sand were basically the same, except for the contents of muscovite and calcite. The content of phyllosilicates in fine sand was higher than that in coarse sand, while the adsorption capacity of clay was also larger than that of coarse sand. An increase in phyllosilicates content can improve the adsorption capacity. $K_{F}(p<0.01)$ and $K_{L}(p<0.05)$ were significantly positively correlated with kaolinite (Table 7). In summary, the fine fractions adsorbed more phosphorus than the coarse fractions, which was a function of particle size and mineral composition. On the one hand, phyllosilicates were concentrated in the fine fractions due to the smaller particle size, leading to higher phyllosilicates and higher adsorption; on the other hand, the smaller particle size resulted in a greater specific surface area and, thus, increased adsorption.

$\mathrm{HPO}_{4}{ }^{2-}$ is the main form of phosphate ion in calcareous soil solution [57], and it can generate dicalcium phosphate with a small amount of exchangeable $\mathrm{Ca}^{2+}$ on the surface of dolomite [13]. Dicalcium phosphate gradually forms octacalcium phosphate with lower solubility, which further slowly transforms into decacalcium phosphate [63]. Eventually, decacalcium phosphates undergoes crystal growth, transforming from amorphous hydroxyapatite to crystalline hydroxyapatite [66]. As these samples were taken from the long-term cultivation areas, there was a gradual accumulation of octacalcium phosphate and decacalcium phosphate in the soil, mainly on the surface of carbonate minerals. Therefore, $\mathrm{Ca}_{8}-\mathrm{P}$, $\mathrm{Ca}_{10}-\mathrm{P}$, and $\mathrm{Ca}-\mathrm{P}$ were significantly positively correlated with dolomite (Table 7).

Soil particle size and mineral composition have a significant influence on the formation of phosphorus. When phosphorus is fixed by calcareous soil, an adsorption reaction on the 
surface of minerals occurs first, thereby forming phosphorus coordination compounds. The compounds slowly deposit on the minerals surface before being fixed by the soil, such as Al-P on the surface of kaolinite and muscovite, Ca-P on the surface of calcite and dolomite, and Fe-P on the surface of amorphous iron oxide. Because calcareous soil is alkaline, the precipitation of Al-P and Fe-P is inhibited [61,67], and the formation of $\mathrm{Ca}_{10}-\mathrm{P}$ with strong stability is beneficial. Therefore, carbonate minerals represent the dominant fixator of phosphorus in calcareous soil [68], particularly in sand. Consequently, in calcareous soil, the form of phosphorus is affected by soil mineral species and particle size. The content of Ca-P fixed by carbonate minerals increases with particle size, whereas kaolinite, muscovite, and iron oxide are enriched in fine fractions, leading to the contents of Al-P and Fe-P decreasing with an increase in particle size.

Clay minerals (such as kaolinite) in the calcareous soil on slope farmland are mainly concentrated in fine fractions, which are predominantly lost via selective migration during the long periods of soil erosion [52]. Thus, the adsorption capacity of clay minerals with respect to phosphorus is much higher than that of other minerals, and the adsorbed phosphorus is mainly the easily available phosphorus, resulting in the easily available phosphorus being adsorbed by clay minerals and then lost with the fine fraction into the water, causing eutrophication. Meanwhile, the loss of fine fractions increases the proportion of coarse fractions, which are rich in carbonate minerals and have a strong phosphorus fixation ability. Phosphate is lost along with clay and fixed by carbonate at the same time, resulting in soil quality degradation and productivity decline. Therefore, it is crucial to control the loss of fine fractions in the management of calcareous soil on slope farmland.

\section{Conclusions}

On the basis of the presented investigation of mechanical composition, mineral composition, phosphorus composition, and the adsorption properties of the soil samples collected from calcareous soil on slope farmland in the TGRA, we found that clay minerals such as kaolinite are mainly concentrated in fine fractions (such as clay and silt), and carbonate minerals such as calcite and dolomite mainly exist in the coarse fractions. Due to the characteristics of soil erosion on slope farmland, long-term selective migration makes the content of clay in soil decrease continuously, and the proportion of coarse fractions increases, which causes a large amount of phosphorus fixed by carbonate minerals in the coarse fractions, leading to degradation of soil quality. On the other hand, the adsorption quantity of clay with respect to phosphorus is much higher than that of other fractions, and the adsorbed phosphorus is the most easily available phosphorus, so the loss of easily available phosphorus via clay leads to the reduction of easily available phosphorus in the soil, aggravating the degradation of soil quality. Meanwhile, this easily available phosphorus enters the water body via the lost clay, resulting in the eutrophication of water body.

Author Contributions: Conceptualization, W.H. and Y.L.; methodology, W.H.; investigation, W.H., and H.Y.; formal analysis, W.H.; resources, Y.L.; writing — original draft preparation, W.H.; writingreview and editing, W.H., H.Y., and Y.L. All authors have read and agreed to the published version of the manuscript.

Funding: This research was funded by Ministry of Ecology and Environment of the People's Republic of China, grant number 2012ZX07104-002.

Institutional Review Board Statement: Not applicable.

Informed Consent Statement: Not applicable.

Data Availability Statement: Data contained within the article.

Acknowledgments: Thanks to Li Yubiao for providing TOPAS software.

Conflicts of Interest: The authors declare no conflict of interest. The funders had no role in the design of the study; in the collection, analyses, or interpretation of data; in the writing of the manuscript, or in the decision to publish the results. 


\section{References}

1. Ministry of Natural Resources of the PRC. National Bureau of Statistics. Communique on the Main Data Achievements of the Second National Land Survey. Available online: http:/ /g.mnr.gov.cn/201701/t20170123_1429533.html (accessed on 14 March 2021).

2. $\mathrm{Xu}, \mathrm{J}$. Some rainfall-related thresholds for erosion and sediment yield in the upper Yangtze River basin. Environ. Geol. 2009, 56, 1183-1192. [CrossRef]

3. Zhang, Q.; Chen, S.; Dong, Y.; Liu, D.; Yang, X.; Yang, Z. Controllability of phosphorus losses in surface runoff from sloping farmland treated by agricultural practices. Land Degrad. Dev. 2017, 28, 1704-1716. [CrossRef]

4. Bai, Y.; Qi, H.; Zhao, T.; Zhou, Y.; Liu, L.; Xiong, J.; Zhou, Z.; Cui, C. Simulation of the responses of rainstorm in the Yangtze River Middle Reaches to changes in anthropogenic aerosol emissions. Atmos. Environ. 2020, 220. [CrossRef]

5. Ministry of Water Resources of the People's Republic of China. Bulletin of Water and Soil Conservation in China in 2019; Ministry of Water Resources of the People's Republic of China: Beijing, China, 2020; p. 44.

6. Shen, Z.; Qiu, J.; Hong, Q.; Chen, L. Simulation of spatial and temporal distributions of non-point source pollution load in the Three Gorges Reservoir Region. Sci. Total Environ. 2014, 493, 138-146. [CrossRef]

7. Sharpley, A.N.; Bergström, L.; Aronsson, H.; Bechmann, M.; Bolster, C.H.; Börling, K.; Djodjic, F.; Jarvie, H.P.; Schoumans, O.F.; Stamm, C.; et al. Future agriculture with minimized phosphorus losses to waters: Research needs and direction. Ambio 2015, 44, 163-179. [CrossRef]

8. Katra, I.; Gross, A.; Swet, N.; Tanner, S.; Krasnov, H.; Angert, A. Substantial dust loss of bioavailable phosphorus from agricultural soils. Sci. Rep. UK 2016, 6, 24736. [CrossRef]

9. Le Moal, M.; Gascuel-Odoux, C.; Ménesguen, A.; Souchon, Y.; Étrillard, C.; Levain, A.; Moatar, F.; Pannard, A.; Souchu, P.; Lefebvre, A.; et al. Eutrophication: A new wine in an old bottle? Sci. Total Environ. 2019, 651, 1-11. [CrossRef]

10. Yu, C.; Gao, B.; Muñoz-Carpena, R.; Tian, Y.; Wu, L.; Perez-Ovilla, O. A laboratory study of colloid and solute transport in surface runoff on saturated soil. J. Hydrol. 2011, 402, 159-164. [CrossRef]

11. Fu, W.; Zhang, X. Global phosphorus dynamics in terms of phosphine. npj Clim. Atmos. Sci. 2020, 3, 51. [CrossRef]

12. Alewell, C.; Ringeval, B.; Ballabio, C.; Robinson, D.A.; Panagos, P.; Borrelli, P. Global phosphorus shortage will be aggravated by soil erosion. Nat. Commun. 2020, 11, 4546. [CrossRef]

13. Tunesi, S.; Poggi, V.; Gessa, C. Phosphate adsorption and precipitation in calcareous soils: The role of calcium ions in solution and carbonate minerals. Nutr. Cycl. Agroecosys. 1999, 53, 219-227. [CrossRef]

14. Barrow, N.J. A mechanistic model for describing the sorption and desorption of phosphate by soil. Eur. J. Soil Sci. 2015, 66, 9-18. [CrossRef]

15. Jalali, M.; Jalali, M. Relation between various soil phosphorus extraction methods and sorption parameters in calcareous soils with different texture. Sci. Total Environ. 2016, 566-567, 1080-1093. [CrossRef]

16. Lu, J.; Li, Z. Discussion on Phosphorus Fixation Matrix in Calcareous Soil. Chin. J. Soil Sci. 1991, 204-206. [CrossRef]

17. Li, Z.; Lu, J. Study on the Phosphorus Fixation Characteristics of Calcium Carbonate and Physical Clay. Soils 1995, 8, 304-310.

18. Borrero, C.; Peña, F.; Torrent, J. Phosphate sorption by calcium carbonate in some soils of the Mediterranean part of Spain. Geoderma 1988, 42, 261-269. [CrossRef]

19. Huang, C.; Xu, J. Soil Science; China Agriculture Press: Beijing, China, 2010; p. 307.

20. Ruehlmann, J.; Körschens, M. Soil particle density as affected by soil texture and soil organic matter: 2 . Predicting the effect of the mineral composition of particle-size fractions. Geoderma 2020, 375, 114543. [CrossRef]

21. Holtan, H.; Kamp-Nielsen, L.; Stuanes, A.O. Phosphorus in soil, water and sediment: An overview. Hydrobiologia 1988, 170, 19-34. [CrossRef]

22. Liu, R.; Wang, Q.; Xu, F.; Men, C.; Guo, L. Impacts of manure application on SWAT model outputs in the Xiangxi River watershed. J. Hydrol. 2017, 555, 479-488. [CrossRef]

23. Gee, G.W.; Or, D. 2.4 Particle-Size Analysis. In Methods of Soil Analysis: Part 4 Physical Methods; Dane, J.H., Topp, G.C., Eds.; Soil Science Society of America, Inc.: Madison, WI, USA, 2002; pp. 255-293.

24. Yong, R.N.; Warkentin, B.P. Introduction to Soil Behavior; Macmillan Co.: New York, NY, USA, 1966; p. 451.

25. Guo, G.; Zhang, Y.; Zhang, C.; Wang, S.; Yan, Z.; Li, F. Partition and characterization of cadmium on different particle-size aggregates in Chinese Phaeozem. Geoderma 2013, 200-201, 108-113. [CrossRef]

26. Makarov, M.I.; Haumaier, L.; Zech, W.; Malysheva, T.I. Organic phosphorus compounds in particle-size fractions of mountain soils in the northwestern Caucasus. Geoderma 2004, 118, 101-114. [CrossRef]

27. Schmidt, M.W.I.; Kogel-Knabaner, I. Organic matter in particle-size fractions from A and B horizons of a Haplic Alisol. Eur. J. Soil Sci. 2002, 53, 383-391. [CrossRef]

28. Mebius, L.J. A rapid method for the determination of organic carbon in soil. Anal. Chim. Acta 1960, 22, 120-124. [CrossRef]

29. Bremner, J.M.; Mulvaney, C.S. Part 2 Nitrogen total. In Methods of Soil Analysis, 2nd ed.; Page, A.L., Miller, R.H., Keeney, D.R., Eds.; American Society of Agronomy: Madison, WI, USA, 1982; Volume WI, pp. 595-624.

30. Schlichting, E.; Blume, H.P.; Stahr, K. Bodenkundliches Praktikum; Blackwell Wissenschafts-Verlag: Berlín, Germany, $1995 ;$ p. 255.

31. Bao, S. Soil and Agricultural Chemistry Analysis, 3rd ed.; Chinese Agriculture Publishing House: Beijing, China, $2000 ;$ p. 495.

32. Olsen, S.R.; Cole, C.V.; Watanabe, F.S.; Dean, L.A. Estimation of Available Phosphorus in Soils by Extraction with Sodium Bicarbonate; Circular No. 939; U.S. Department of Agriculture, U.S. Government Printing Office: Washington, DC, USA, 1954. 
33. Kaila, A. Determination of total organic phosphorus in samples of mineral soils. Agric. Food Sci. 1962, 34, 187-196. [CrossRef]

34. Jiang, B.; Gu, Y. A suggested fractionation scheme of inorganic phosphorus in calcareous soils. Fertil. Res. 1989, 20, 159-165. [CrossRef]

35. Samanta, A.; Chanda, D.K.; Das, P.S.; Ghosh, J.; Dey, A.; Das, S.; Mukhopadhyay, A.K. Synthesis of mixed calcite-calcium oxide nanojasmine flowers. Ceram. Int. 2016, 42, 2339-2348. [CrossRef]

36. Wayne Nesbitt, H.; Markovics, G. Weathering of granodioritic crust, long-term storage of elements in weathering profiles, and petrogenesis of siliciclastic sediments. Geochim. Cosmochim. Acta 1997, 61, 1653-1670. [CrossRef]

37. Hans, J. Factors of Soil Formation: A System of Quantitative Pedology; Dover Publications, Inc.: New York, NY, USA, $1994 ;$ p. 281.

38. Tang, X.; Wu, M.; Li, Q.; Lin, L.; Zhao, W. Impacts of water level regulation on sediment physic-chemical properties and phosphorus adsorption-desorption behaviors. Ecol. Eng. 2014, 70, 450-458. [CrossRef]

39. Zhang, M.; Li, C.; Li, Y.C.; Harris, W.G. Phosphate minerals and solubility in native and agricultural calcareous soils. Geoderma 2014, 232-234, 164-171. [CrossRef]

40. Bohn, H.L.; McNeal, B.L.; O'Connor, G.A. Soil Chemistry, 3rd ed.; John Wiley \& Sons Inc.: Hoboken, NJ, USA, $2001 ;$ p. 329.

41. Madejová, J. FTIR techniques in clay mineral studies. Vib. Spectrosc. 2003, 31, 1-10. [CrossRef]

42. Ndzana, G.M.; Huang, L.; Wang, J.B.; Zhang, Z.Y. Characteristics of clay minerals in soil particles from an argillic horizon of Alfisol in central China. Appl. Clay Sci. 2018, 151, 148-156. [CrossRef]

43. Brigattia, M.F.; Gala, E.; Theng, B.K.G. Chapter 2 Structure and Mineralogy of Clay Minerals. In Handbook of Clay Science; Bergaya, F., Lagaly, G., Eds.; Elsevier: Amsterdam, The Netherland, 2013; Volume 5, pp. 21-81.

44. Rakhimova, N.R.; Rakhimov, R.Z.; Bikmukhametov, A.R.; Morozov, V.P.; Eskin, A.A.; Lygina, T.Z.; Gubaidullina, A.M. Role of Clay Minerals Content and Calcite in Alkali Activation of Low-Grade Multimineral Clays. J. Mater. Civil Eng. 2020, $32,4020198$. [CrossRef]

45. Oinuma, K.; Hayashi, H. Infrared study of mixed-layer clay minerals. Am. Mineral. 1965, 50, $1213-1227$.

46. Gaffey, S.J. Spectral reflectance of carbonate minerals in the visible and near infrared (0.35-2.55 microns); calcite, aragonite, and dolomite. J. Geophys. Res. 1987, 92, 1429-1440. [CrossRef]

47. Gunasekaran, S.; Anbalagan, G.; Pandi, S. Raman and infrared spectra of carbonates of calcite structure. J. Raman. Spectrosc. 2006, 37, 892-899. [CrossRef]

48. Wen, L.; Liang, W.; Zhang, Z.; Huang, J. The Infrared Spectroscopy of Minerals; Chongqing University Press: Chongqing, China, 1988; p. 190.

49. Farmer, V.C. The Infrared Spectra of Minerals; Mineralogical Society of Great Britain: London, UK, $1974 ;$ p. 539.

50. De Almeida Azzi, A.; Osacký, M.; Uhlík, P.; Čaplovičová, M.; Zanardo, A.; Madejová, J. Characterization of clays from the Corumbataí formation used as raw material for ceramic industry in the Santa Gertrudes district, São Paulo, Brazil. Appl. Clay Sci. 2016, 132-133, 232-242. [CrossRef]

51. Raei, B.; Asadi, H.; Moussavi, A.; Ghadiri, H. A study of initial motion of soil aggregates in comparison with sand particles of various sizes. Catena 2015, 279-286. [CrossRef]

52. Defersha, M.B.; Melesse, A.M. Effect of rainfall intensity, slope and antecedent moisture content on sediment concentration and sediment enrichment ratio. Catena 2012, 90, 47-52. [CrossRef]

53. Liu, X.; Zhang, G.; Heathman, G.C.; Wang, Y.; Huang, C. Fractal features of soil particle-size distribution as affected by plant communities in the forested region of Mountain Yimeng, China. Geoderma 2009, 154, 123-130. [CrossRef]

54. Koiter, A.J.; Owens, P.N.; Petticrew, E.L.; Lobb, D.A. The role of soil surface properties on the particle size and carbon selectivity of interrill erosion in agricultural landscapes. Catena 2017, 153, 194-206. [CrossRef]

55. Lin, J.; Zhu, G.; Wei, J.; Jiang, F.; Wang, M.; Huang, Y. Mulching effects on erosion from steep slopes and sediment particle size distributions of gully colluvial deposits. Catena 2018, 160, 57-67. [CrossRef]

56. Song, K.; Xue, Y.; Zheng, X.; Lv, W.; Qiao, H.; Qin, Q.; Yang, J. Effects of the continuous use of organic manure and chemical fertilizer on soil inorganic phosphorus fractions in calcareous soil. Sci. Rep. UK 2017, 7, 1-9. [CrossRef]

57. Azam, H.M.; Alam, S.T.; Hasan, M.; Yameogo, D.D.S.; Kannan, A.D.; Rahman, A.; Kwon, M.J. Phosphorous in the environment: Characteristics with distribution and effects, removal mechanisms, treatment technologies, and factors affecting recovery as minerals in natural and engineered systems. Environ. Sci. Pollut. Res. 2019, 26, 20183-20207. [CrossRef]

58. Tiessen, H.; Stewart, J.W.B.; Moir, J.O. Changes in organic and inorganic phosphorus composition of two grassland soils and their particle size fractions during 60-90 years of cultivation. J. Soil Sci. 1983, 34, 815-823. [CrossRef]

59. Audette, Y.; O'Halloran, I.P.; Paul Voroney, R. Kinetics of phosphorus forms applied as inorganic and organic amendments to a calcareous soil. Geoderma 2016, 262, 119-124. [CrossRef]

60. Tahir, S.; Marschner, P. Clay Addition to Sandy Soil Reduces Nutrient Leaching-Effect of Clay Concentration and Ped Size. Commun. Soil Sci. Plan 2017, 48, 1813-1821. [CrossRef]

61. Gérard, F. Clay minerals, iron/aluminum oxides, and their contribution to phosphate sorption in soils-A myth revisited. Geoderma 2016, 262, 213-226. [CrossRef]

62. Xiao, Y.; Zhu, X.; Cheng, H.; Li, K.; Lu, Q.; Liang, D. Characteristics of phosphorus adsorption by sediment mineral matrices with different particle sizes. Water Sci. Eng. 2013, 6, 262-271. [CrossRef]

63. Li, X. Soil Chemistry; Higher Education Press: Beijing, China, 2001; p. 406.

64. Griffin, R.A.; Jurinak, J.J. Kinetics of the Phosphate Interaction with Calcite. Soil Sci. Soc. Am. J. 1974, 38, 75-79. [CrossRef] 
65. Cui, Z.; Fang, H.; Huang, L.; Ni, K.; Reible, D. Effect of surface heterogeneity on phosphorus adsorption onto mineral particles: Experiments and modeling. J. Soil Sediment 2017, 17, 2887-2898. [CrossRef]

66. Griffin, R.A.; Jurinak, J.J. The Interaction of Phosphate with Calcite. Soil Sci. Soc. Am. J. 1973, 37, 847-850. [CrossRef]

67. Kasama, T.; Watanabe, Y.; Yamada, H.; Murakami, T. Sorption of phosphates on Al-pillared smectites and mica at acidic to neutral pH. Appl. Clay Sci. 2004, 25, 167-177. [CrossRef]

68. Carreira, J.A.; Viñegla, B.; Lajtha, K. Secondary $\mathrm{CaCO}_{3}$ and precipitation of P-Ca compounds control the retention of soil $\mathrm{P}$ in arid ecosystems. J. Arid. Environ. 2006, 64, 460-473. [CrossRef] 